Article

\title{
Supply Chain Resilience: Unleashing the Power of Collaboration in Disaster Management
}

\author{
Muhammad Umar *(D) and Mark Wilson (D) \\ Faculty of Agribusiness and Commerce, Lincoln University, Lincoln 7674, New Zealand; \\ mark.wilson@lincoln.ac.nz \\ * Correspondence: muhammad.umar@lincoln.ac.nz
}

check for

updates

Citation: Umar, M.; Wilson, M. Supply Chain Resilience: Unleashing the Power of Collaboration in Disaster Management. Sustainability 2021, 13, 10573. https://doi.org/ $10.3390 /$ su131910573

Academic Editor: John T. Cooper

Received: 29 July 2021

Accepted: 21 September 2021

Published: 23 September 2021

Publisher's Note: MDPI stays neutral with regard to jurisdictional claims in published maps and institutional affiliations.

Copyright: (C) 2021 by the authors. Licensee MDPI, Basel, Switzerland. This article is an open access article distributed under the terms and conditions of the Creative Commons Attribution (CC BY) license (https:/ / creativecommons.org/licenses/by/ $4.0 /)$.

\begin{abstract}
This study builds on the extant literature of supply chain collaboration, specifically, vertical and horizontal collaboration, and examines how these capabilities influence the resilience of supply chains that experience regular natural disasters in rural communities, as their economic wellbeing relies heavily on the continuation of these supply chains. A multiple case study approach has been adopted to investigate the role of collaboration within food supply chains of two different South Asian regions. This context was selected because these regions are prone to regular natural disruptions, and these food supply chains also play a crucial role in the disaster relief process. The data revealed that effective communication, mutual dependence, information sharing, informal financial support, and trust are some of the components of supply chain collaboration that enhance the overall resilience of supply chains in natural disasters.
\end{abstract}

Keywords: collaboration; supply chain resilience; food supply chains; rural communities

\section{Introduction}

Resilient agriculture supply chains are particularly important for the rural communities, as their economic wellbeing relies heavily on the smooth running of these supply chains. Indeed, the growing complexity of the current business environment in which these agricultural supply chains operate demands more flexible and collaborative operations. Due to this complexity, firms are more exposed to supply chain disruptions that arise, especially from natural disaster events. Multiple management activities are involved in supply chain management, such as procurement, inventory, distribution, and logistics management [1]. The planning and execution of all these activities is a challenging task that demands efficient and effective coordination of informational, relational, and financial flows across the boundaries of a firm [2]. However, every supply chain activity has inherent risks and can be exposed to some unexpected disruptions. Natural disasters are a major cause of supply chain disruptions and can result in major breakdowns of distribution linkages and production nodes, especially in rural areas with poor infrastructure and a lack of access to basic resources [3]. Managing this rapidly changing risk landscape is a challenge that demands that supply chains develop stronger disaster-resilient characteristics $[4,5]$.

Supply chain resilience is a concept that has been found to reduce the impact of disruptions. Even for rare but significant events, for which the probability of occurrence is low, the impact could be devastating [6]. Resilience helps supply chains to survive and recover to either the same state as prior to the disaster (resilience) or to a better position that is termed 'thriving' in the resilience lexicon [7]. As such, resilience and thriving can be achieved when all the actors of a supply chain take certain actions to become more agile and adaptive [8]. One of these key actions is to build collaborative networks [9]. Indeed, collaboration among the supply chain partners is considered the 'glue' that holds all stakeholders together in difficult times [10]. A number of authors have discussed the importance of collaboration in achieving supply chain resilience [11-13]. However, while collaboration is considered a key element of supply chain resilience [14], empirical 
insights into how collaboration contributes to achieving resilience are unestablished. This is especially true for developing countries and food networks in particular-hence, we focused on food networks in Southeast Asia, specifically Pakistan. Pakistan is prone to different types of hazards due to its geographic and climatic conditions [15]. The loss of livestock, crops, and infrastructure due to floods alone has seen Pakistan suffer USD 30 billion worth of losses in the last 60 years. Over this time, more than eight thousand people have lost their lives, and more than $400,000 \mathrm{sq}$. $\mathrm{km}$ of land have been affected. In 2010, for example, floods caused a USD 10 billion loss to the economy, 2000 people lost their lives, and a total area of more than $160,000 \mathrm{sq}$. $\mathrm{km}$ was affected [16]. Indeed, resilience is even more important in these countries, as most supply chain operations are compromised to varying degrees by mismanagement and corruption. Despite these issues, experience has shown that these food chains remain operational even when subjected to a myriad of supply chain disruptions, often due to natural disasters. As such, it is a worthy context to study the role of collaboration in disaster management.

Supply chain firms do not operate in isolation. Rather, they are embedded in networks that possess a variety of diverse resources and capabilities [17]. These resources often span a firm's boundaries and reside in inter-firm relationships and the wider network [18]. The recombination of these network resources provides new opportunities for firms to gain market advantage and to reduce uncertainties [19]. This recombination (or co-creation) of resources requires supply chain actors to collaborate both vertically and horizontally. Vertical collaboration involves firms in other tiers of the supply chain, such as buyers and suppliers, while horizontal collaboration involves other firms within the same tier, such as wholesalers, working together [20]. Yet, the literature on collaboration mostly lacks empirical evidence that extends beyond dyadic buyer/supplier relationships [21]. Indeed, at the network level, there is a dearth of empirical insight. As such, this study was an investigation into the supply chain networks of two quite different rural regions of Pakistan. The intent was to discern in greater detail the underlying dimensions of collaboration and how these promote firm and overall supply chain resilience.

Food supply chains were selected for the research setting, as these supply chains are essential in a rural economy. They not only materially impact the health, hunger, and poverty of the populace, but they are also important channels for providing relief supplies during disasters. Hence, the following was the primary research question:

RQ: How do vertical and horizontal collaborations contribute to supply chain resilience in disaster-prone rural regions?

Before justifying the methodology and presenting the findings of this study, we will present a review of the literature on the key concepts of collaboration and resilience.

\section{Literature Review}

\subsection{Supply Chain Resilience}

From the early nineteenth century, the main strategy to counter supply chain disruptions was to cover any risks by holding excess inventory. Safety stock to deal with uncertainties remained a key strategy for a considerable time. To satisfy customer demand quickly and to manage risks, quick response mechanisms were developed, such as vendor managed inventory (VMI), and just-in-time (JIT) [22]. However, these quick response systems have increased the vulnerability of supply chains. The reason is that they reduced buffer and safety stocks. In these newer models, supply and demand are more closely matched, yet they are more likely to break down when disrupted [23]. Hence, supply chain risk management was an appropriate strategic response to these disruptions. However, many scholars note that traditional risk management practices are lacking in their ability to comprehend the complexities of supply chains [24]. Scholars are becoming increasingly aware of the shortcomings of risk management approaches [25] and have pointed to the notion of resilience as a result. In simple terms, resilience can be defined as "the capacity of a firm to survive, resist and adapt in the face of turbulent change" [26]. 
Resilience as a concept has its origins in the fields of physics, ecology, engineering, sociology, disaster management, supply chains [4], and development psychology [27]. For example, in ecology, resilience can be defined as the ability of a system to survive a disruption and rebound back to its original position while still maintaining integrity, diversity, and processes [28]. Similarly, resilience in the humanitarian supply chain context emphasizes the different approaches a system can use to respond to a natural disaster [29]. As it is an emerging discipline, there is great diversity in the definitions of supply chain resilience.

For the most part, supply chain resilience is defined as the ability of the supply chain to maintain a required level of preparedness/readiness, response, and recovery capabilities to manage different disruptions. This ability enables supply chains to rebound to their original state, or to an even better state post-disruption [30-32]. The readiness stage of resilience develops certain capabilities that involve the coordination of resources to detect and prevent future disruptions in the supply chain [33]. Response stage capabilities primarily involve actively dealing with disasters and providing information related to a particular disruption to all supply chain entities. Finally, recovery stage capabilities involve the interactions among all actors and the sharing of resources to bounce back to normal operations [34].

The list of strategies discussed in the literature includes broad approaches, such as creating redundancies, flexibility, agility, enhancing visibility, and increasing velocity or responsiveness [35,36]. More specific practices include information sharing, risk management culture, and network reconfigurations [2]. Other authors, such as Christopher and Peck [7], argue that supply chain resilience elements include supply base strategy, risk categorization, supply chain risk management, and collaboration strategies. They also argue that agility, availability, efficiency, redundancy, and visibility are critical factors.

Goranson [37] argued for differentiation between agility and flexibility, with flexibility being a planned adaptation strategy to sudden but expected disruptions, while agility is unplanned adaptation to unexpected circumstances. Nevertheless, a few authors consider flexibility as being part of agility (for example, Stevenson and Spring [38]). Similarly, Rice and Caniato [39] argue that flexibility as well as redundancy both have good potential for enhancing resilience. Redundancy is the concept of holding excess capacity and inventory that can be used to cover demand variability and lost capacity due to disasters. Conversely, flexibility is the ability to redeploy previously committed capacity and inventory. Likewise, Lee [40] also suggested that to combat demand and supply uncertainties, supply chain processes need to possess agility, adaptability, and alignment to achieve superior performance. This is the well-known 'Triple A' of supply chain resilience. Here, agility means responding to short-term changes quickly [41]. Adjusting the design of the supply chain to meet structural shifts in the market is called alignment. Alignment essentially means exchanging information and knowledge frequently with supply chain partners to eliminate waste and achieve better system performance [42]. Adaptability is the ability to adapt to a new situation in the recovery phase. Adaptability can be considered a key trait in resilient supply chains, as the new state post-disruption can be very different from the original [8]. The dynamic nature of adaptive capability makes it easier for supply chains to bounce back or achieve a more appropriate state post-disruption.

In general, the literature on supply chain resilience, while informative, is primarily focused on multiple fragmented perspectives of resilience $[6,14,25,26]$. These divergent views actually serve to highlight the importance of this topic. Similarly, a number of necessary elements that form the resilience concept, such as agility, adaptability, and flexibility, are also discussed separately.

It is argued here that most of these concepts can be categorized into the main elements of agility, adaptability, and alignment, similar to Lee's [40] conceptualization. Support is also found for the idea that flexibility, velocity, visibility, risk management, and supply base strategy are supply chain agility components $[43,44]$. The concepts of supply chain adaptability and alignment are also well linked to resilience, as mentioned by a number of researchers $[30,45,46]$. Yet, resilience seems to be primarily discussed from a firm 
perspective [47], ignoring the fact that these same firms are embedded in supply chain networks. However, as the chain is only as strong as its weakest link, achieving supply chain resilience requires collaboration among all the actors.

\subsection{Supply Chain Collaboration}

Supply chain collaboration is a multifaceted concept embedded in inter-firm relationships. The strength of these relationships ranges from simple arms-length relations to high level alliancing, including the behaviour of 'coopetition' where firms collaborate with their competitors [48]. Collaboration has been researched from a number of perspectives. In the supply chain context, collaboration can be expressed through the behaviours of information sharing, joint planning, goal congruence, joint problem solving, risk and reward sharing, and the sharing of resources [49]. Collaboration, through trust and commitment, can act as the glue by holding together different firms and enabling them to build capabilities necessary for resilience. Indeed, supply chain collaborative relationships can be divided into two main categories, vertical and horizontal collaboration [50]. During any disruption, firms collaborate with relief providers, governments, and their competitors at a horizontal level. Similarly, at a vertical level, these firms, necessarily also collaborate with their suppliers and buyers [51].

The literature on supply chain collaboration focuses primarily on the different types and stages of supply chain relationship development [52]. The literature also addresses the strategies and theoretical foundations of collaboration [53]. The types of relationships discussed include transactional, relational, and fully coordinated [49]. Other concepts frequently researched include trust and commitment, reward systems, and power among the supply chain actors [54]. Further, Simatupang and Sridharan [49] proposed that information sharing, decision alignment, and incentives are important elements of supply chain collaboration. Information sharing describes the extent to which supply chain members share information with each other in efficient and effective ways [55]. Decision synchronization or alignment is an integrated approach to making decisions that is applied to different levels of the supply chain [51]. Finally, incentive alignment refers to the sharing of risks and benefits among supply chain partners [10].

Cao and Zhang [53]'s study is one of the most widely cited works on supply chain collaboration. They have identified seven components of collaboration-information sharing, goal alignment, decision synchronization, communication, joint knowledge creation, resource sharing, and incentive alignment. Scholten and Schilder [20] also used these elements to investigate the role of collaboration in supply chain resilience. Indeed, while collaboration has been widely researched, it is lacking a more detailed conceptualization within a network resilience setting [56,57].

\subsection{Food Supply Chains in Developing Economies}

Several studies have examined food supply chains in general [58-60], both in developed and underdeveloped countries. However, very few of these studies have examined the resilience of these supply chains [61,62]. Even fewer have investigated them in the context of natural disasters, and those that have typically focused on developed countries $[46,63]$.

In general, food supply chains in South Asian countries are very fragmented and complex [64]. Rapid responses to disasters can be hampered, as this complexity makes these supply chains highly vulnerable when communication and transport infrastructure is disrupted. Acharyulu and Mathew [58] assess these flows as 'disjointed' supply chains. On average, food passes through an average of six middlemen before reaching the end customers, which often results in higher prices and lower quality food.

To improve the disaster response for food supply chains, Douglas [65] contends that strengthening surrounding community resilience is critical. Here, resilience can be achieved through ensuring local food stocks and shelter, supporting local community groups, and working with local governments. Aggarwal and Joshi [66] argue that strategies 
to reduce the vulnerability of local food supply chains should be based on a combination of technology and policy. Yet, to achieve these goals, a deeper understanding of how the local food supply chain works in practice and how these supply chains interact with the local community is necessary.

Improving community resilience helps to reduce vulnerability during periods of disaster. In their studies, López-Marrero and Tschakert [67] summarized the points required for enhancing resilience in the flood-prone area of Puerto Rico. In particular, this requires the promotion of effective collaboration between emergency managers and local community members. They also stress the importance of developing a proper disaster management framework and support for social cumulative learning based on previous disaster experience. Here, the local community consists of mostly individual households, but also includes local government members and agencies [68].

At the same time, food supply chains and individual firms can also benefit significantly when overall community resilience is enhanced. This can be achieved through trustworthy collaboration with international and national humanitarian organizations, and by making their own supply chains more resilient. Guarnizo [69] has also noted the importance of adjustment mechanisms (social organization, economic relationships, technology, and cultural arrangements) in community resilience for natural disasters. These mechanisms are different for each phase of a disaster. In social organizations, the most important mechanism is the family unit. Extended family relationships provide a network of mutual assistance to cope with the stress of the disaster. Mutual aid and self-help groups are other important adjustment mechanisms in this category. Subsequently, retailers and local food supply chains could also be important social/economic adjustment factors [63]. Indeed, there are a number of adjustment factors included under the category of economic relationships. Rural producers adopt different risk aversion/avoidance mechanisms, such as the diversification of crops, different storage schemes, and switching to non-agricultural activities during times of disaster. Communities can also develop marketing strategies and trade linkages with regional markets to access alternative sources of supply and income. Banks and other financial institutions can decrease/suspend interest rates on loans during the recovery phase for rebuilding activities [70]. Furthermore, communities use technology to adjust during times of disasters. They use new methods of soil management and solar energy to run 'tube' wells and the latest storage techniques to store food. Moreover, there are cultural mechanisms, behaviours, and beliefs to cope and adapt to disasters. Obviously, different societies perceive disasters in different ways. They use unique knowledge-sharing techniques to pass on knowledge and lessons learned to the next generation [69].

In this study, we particularly focused on the rural communities of two provinces in Pakistan. These rural communities consist of villages and small towns surrounding the larger cities in these two regions. There are food wholesale markets present at strategic places throughout these regions. These wholesale markets provide a platform for the farmers in the communities to sell their agricultural products and help them connect with buyers. These two regions in Pakistan were selected because they are vulnerable to natural disasters, especially floods and earthquakes. In addition, the majority of the population is still living in these rural areas and the impact of natural disasters is the highest in these rural areas, as they lack basic infrastructure. More detail on the selection of the regions is presented in Section 3.

\section{Methodology}

The aim of this study was to empirically investigate the collaborative activities of food supply chains in rural communities that help build supply chain resilience. To achieve this, an abductive exploratory approach was considered appropriate. Hence, a multiple case study method largely inspired by Yin [71] and Miles and Huberman [72] was adopted to provide deeper insights into the nature of collaborative activities among supply chain partners in the region. 


\subsection{Area Selection}

As this research was focused on food supply chain/network resilience to disasters, especially in the context of developing economies, Pakistan was considered a suitable sample frame, as its economic and disaster profile fitted the research requirements. The next step was to define the regions where disasters occur frequently. To help with this selection, the researchers contacted the National Disaster Management Authority of Pakistan (NDMA), which deals with the whole spectrum of disaster management activities in Pakistan, as well as the South Asian Disaster Knowledge Network (www.saarc-sadkn.org, accessed on 23 September 2020), which is a knowledge-sharing platform among different stakeholders of SAARC (South Asian Association of Regional Cooperation) countries. From these discussions, two regions that have experienced disasters frequently or annually were purposively selected. The first area was the Punjab Province, which is predominantly agricultural land. This area is badly affected by severe floods almost annually [16]. The second region was the Khyber Pakhtun Khwa (KPK) Province, which is vulnerable to earthquakes as well as floods [73]. Polar sampling was used to select these two different provinces in order to provide interesting comparisons. Such polar cases help researchers to understand, describe, and analyse wider characteristics of observed phenomena [74].

\subsection{Sampling}

Purposeful sampling was used to select four commercial food supply chains within these two regions. These diverse supply chains were chosen because they would be more likely to shed light on the nature of collaboration, which is crucial for an overall understanding of supply chain resilience. The two food types (fresh produce and a staple food-rice) were specifically selected in order to draw direct comparisons between chains and regions. Furthermore, the food chain types were selected because they contribute the most towards providing relief for the population during natural disasters. The case codes are noted in Table 1 below.

Table 1. Case Codes.

\begin{tabular}{cccc}
\hline \hline Region: & Supply Chain: & $\begin{array}{c}\text { Fresh Produce } \\
\text { (Case 1) }\end{array}$ & $\begin{array}{c}\text { Staple-Rice } \\
\text { (Case 2) }\end{array}$ \\
\hline & Punjab (Region 1) & C1R1 & C2R1 \\
\hline KPK (Region 2) & C1R2 & C2R2 \\
\hline
\end{tabular}

\subsection{Data Collection}

The primary means of data collection was through face-to-face interviews, which were supported by observations, informal conversations, field notes, documents, reports, and a review of archival secondary sources. Semi-structured interviews were conducted using a rigorously developed research protocol. Most of the interviews were individual one-to-one interviews, however, on several occasions, group interviews were also conducted. These group interviews, which drew on the varied experiences of the people involved, gave greater insights into the complex collaboration/resilience phenomena.

Using purposive sampling, key firms and commission agents in the fresh produce and grain markets of R1 and R2 were contacted. Other than referrals from the Disaster Management Cell in the government, internet and social media platforms were also used for this purpose. Once contact was made, a 'snowball' sampling was applied to reach up and down the respective supply chains to gain an end-to-end view. While selecting informants, three factors were used as guidelines-knowledge (had experienced a disaster and/or its effects in the recent past), willingness to participate, and a diversity of business views. In total, 52 people were approached for an interview, and a final sample of $n=37$ agreed to participate, providing a response rate of $71 \%$ (see Table 2). 
Table 2. Key informants and sample information.

\begin{tabular}{|c|c|c|c|c|}
\hline $\begin{array}{l}\text { Case }(C) \text { and } \\
\text { Region (R) }\end{array}$ & Position in the Supply Chain (Tier) & NVivo Code & Key Informant & $\begin{array}{l}\text { Total Experience } \\
\text { (Years) }\end{array}$ \\
\hline \multirow[t]{11}{*}{ C1R1 } & $\begin{array}{l}\text { Focal Wholesale Market } \\
\text { Commission Agent (CA) }\end{array}$ & CA1-C1R1 & Business Owner & $>15$ \\
\hline & $\begin{array}{l}\text { Focal Wholesale Market } \\
\text { Commission Agent (CA) }\end{array}$ & CA2-C1R1 & Business Owner & Not available (NA) \\
\hline & Supplier: Farmer (Fr) & Fr1-C1R1 & Farm Owner & $>15$ \\
\hline & Supplier: Farmer (Fr) & Fr2-C1R1 & Farm Owner & $>10$ \\
\hline & Supplier: Middleman (MM) & MM1-C1R1 & Business Owner & NA \\
\hline & Supplier: Middleman (MM) & MM2-C1R1 & Business Owner & 12 \\
\hline & Distributor: Wholesaler (WS) & WS1-C1R1 & Manager & $>20$ \\
\hline & Distributor: Wholesaler (WS) & WS2-C1R1 & Manager & $>10$ \\
\hline & Retailer $(\mathrm{Rt})$ & Rt1-C1R1 & Supply Chain Manager & $>5$ \\
\hline & Retailer (Rt) & Rt2-C1R1 & Business Owner & $>10$ \\
\hline & $\begin{array}{l}\text { Market Committee } \\
\text { Government Representative (GR) }\end{array}$ & GR1-C1R1 & Town planner & NA \\
\hline \multirow[t]{10}{*}{ C2R1 } & $\begin{array}{l}\text { Focal Wholesale Market } \\
\text { Commission Agent (CA) }\end{array}$ & CA1-C2R1 & Business Owner & $>20$ \\
\hline & $\begin{array}{l}\text { Focal Wholesale Market } \\
\text { Commission Agent (CA) }\end{array}$ & CA2-C2R1 & Business Owner & NA \\
\hline & Supplier: Farmer (Fr) & Fr1-C2R1 & Landlord & $>10$ \\
\hline & Supplier: Farmer (Fr) & Fr2-C2R1 & Farm Manager & $>5$ \\
\hline & Supplier: Farmer (Fr) & Fr3-C2R1 & Landlord & $>10$ \\
\hline & Supplier: Trader (Tr) & Tr1-C2R1 & Business Owner & NA \\
\hline & Supplier: Trader (Tr) & $\operatorname{Tr} 2-\mathrm{C} 2 \mathrm{R} 1$ & Business Owner & $>5$ \\
\hline & Distributor: Brokers (Br) & Br1-C2R1 & Manager & $>10$ \\
\hline & Retailer (Rt) & Rt1-C2R1 & Planning officer & NA \\
\hline & Labour Supplier (Ls) & Ls1-C2R1 & Business Owner & NA \\
\hline \multirow[t]{10}{*}{ C1R2 } & $\begin{array}{l}\text { Focal Wholesale Market } \\
\text { Commission Agent (CA) }\end{array}$ & CA1-C1R2 & Business Owner & NA \\
\hline & $\begin{array}{l}\text { Focal Wholesale Market } \\
\text { Commission Agent (CA) }\end{array}$ & CA2-C1R2 & Business Owner & NA \\
\hline & Supplier: Farmer (Fr) & Fr1-C1R2 & Farm Owner & $>20$ \\
\hline & Supplier: Farmer (Fr) & Fr2-C1R2 & Farm Manager & $>10$ \\
\hline & Supplier: Middleman (MM) & MM1-C1R2 & Business Owner & NA \\
\hline & Distributor Wholesaler (WS and CA) & CA3-C1R2 & Manager & NA \\
\hline & $\begin{array}{c}\text { Distributor } \\
\text { Wholesaler (WS and CA) }\end{array}$ & CA4-C1R2 & Manager & $>15$ \\
\hline & Retailer (Rt) & Rt1-C1R2 & Business Owner & NA \\
\hline & Retailer (Rt) & Rt2-C1R2 & Business Owner & NA \\
\hline & Market Committee Member (MC) & MC1-C1R2 & Coordinator & NA \\
\hline \multirow[t]{6}{*}{$\mathrm{C} 2 \mathrm{R} 2$} & Distributor Wholesaler (WS) & WS1-C2R2 & Manager & $>10$ \\
\hline & Distributor Wholesaler (WS) & WS2-C2R2 & Manager & $>20$ \\
\hline & Distributor Wholesaler (WS) & WS3-C2R2 & Manager & NA \\
\hline & Distributor Wholesaler (WS) & WS4-C2R2 & Manager & NA \\
\hline & Retailer (Rt) & Rt1-C2R2 & Manager & $>15$ \\
\hline & Retailer (Rt) & Rt2-C2R2 & Manager & $>10$ \\
\hline
\end{tabular}

The majority of respondents permitted the digital recording of the interview, and for those that refused $(n=5)$, field notes were taken. While the main sources of data were the transcripts derived from the different stages of the four supply chains, other observations were made by repeatedly visiting the main markets in the region. These observations focused on the nature of the interactions between the respondents and their suppliers and buyers, and the state of the physical infrastructure, such as storage facilities and transportation. Secondary data sources, such as information sharing sheets, rate lists, tax documents, safety rules, newspaper articles, and other reports written on these chains were also collected. All of the data were transcribed side-by-side with these interviews, and 
a translation service web application (Transcribe Wreally, transcribe.wreally.com, accessed on 23 August 2020) was used for these transcriptions.

\subsection{Analysis}

In qualitative studies, data analysis starts alongside the data collection. As such, field interactions with the respondents, as well as the transcripts, helped in generating and refining the themes as well as strengthening the findings of this research. The transcribed files were shared with the respondents and feedback was sought [75], thus improving the validity of the research. After verification by the participants, all of the data were coded and concepts were developed iteratively. Based on these codes and concepts, themes were generated. Queries were then run in NVivo 11 software to capture and display the data. The data were compared to the literature and theories to generate the findings.

The coding of the data was a complex process. Even from small paragraphs, more than one code and concept could emerge. The development of codes, categories, and themes in NVivo 11 was accomplished using the four-step approach of Silver and Lewins [76]. It also drew on a number of other general approaches to coding data by other authors [71,72]. Finally, the following measures were taken to address reliability and validity concerns for this study (Table 3).

Table 3. Measures of reliability and validity in qualitative research.

\section{Criteria}

Credibility (Internal Validity)

Credibility establishes the extent to which the research finding is a true interpretation of the participants' original views.

\section{Study Response}

a) Prolonged engagement in the field. The researcher was familiar with the local culture and contact was established with respondents long before the data collection stage.

b) Multiple case studies were used in the study, which is a well-established approach backed by multiple recognized researchers in the field.

c) Data triangulation was employed. This strategy made it easy to cross-check the findings with different data sources. For example, data from interviews were triangulated with observations and secondary data.

d) Respondents were given full entitlement to withdraw from the study anytime. Only genuinely interested respondents were chosen to collect the data.

e) Peer debriefing: the researcher continuously received support and feedback from peers. The researcher was also part of the Resilient Organization, New Zealand, which provided support during this study.

a) Detailed interview protocol was prepared to collect the data. This protocol includes the description of the research, concise questions about the phenomenon, and has the complete list of prompt questions asked during the process. This can help future researchers follow the same procedures to get similar results.

This refers to the stability of the results over time.

Transferability (External Validity)

The level to which results from one case study or the real world can be applied to another case study in a different context. a) Multiple case studies were conducted in similar conditions, which further enhances the transferability of this study.

b) Purposeful sampling was used, and this helped the researcher to stay focused on the key informants. It helped the researcher uncover in-depth findings.
Conformability (Objectivity)

This refers to the degree to which the results from one case study can be confirmed by other researchers. a) Full details of the participants were collected in the process. Participants were also given chance to read and give feedback on the transcripts. Similarly, the interpretation chapters also include the quotes from the participants' interviews.

\section{Results}

The results found show that collaboration is active on both the vertical and horizontal levels within these networks, and is a necessary condition for enhanced resilience. At a vertical level, buyers and suppliers collaborate, and at a horizontal level, there is clear collaboration between actors on the same tier (such as different wholesalers in the same 
market, working together) and the government. It seems that collaboration is a key element for the overall supply chain system to survive and thrive in difficult times.

Section 4.1 outlines in detail the vertical collaborative activities that have emerged from the data, including effective communication and information sharing, mutual dependence, non-institutional financial support, utilizing network resources, and trust. Following this, in Section 4.2, horizontal level collaboration is discussed, in particular, coopetition and government support.

\subsection{Vertical Collaboration}

\subsubsection{Effective Communication and Information Sharing}

The results found show that effective communication and information sharing directly contribute to supply chain resilience. They not only increase visibility but also help to achieve flexibility and velocity, and they foster adaptability to new situations. This is particularly relevant to commercial operations of supply chains and aids in building innate resilience to disasters.

In order to achieve resilience, supply chain partners need to consider the role of telecommunications, especially mobile phones and other media sources, such as television. This helps achieve connectivity and coordination during the response and recovery phases of a disaster. A key resilience investment was the installation of signal boosters at strategic locations designed with very resilient construction standards by multinational telecommunication companies. This greater accessibility and cell coverage facilitates velocity (that is, speedy response in the supply chain). However, when mobile coverage failed due to earthquake damage, supply chain actors were forced to travel long distances and use alternative channels to acquire supplies or rely on buffer stocks. Mobile phone communication is more critical in Region 2 (R2). One good example of the use of mobile phones to prepare for an expected flood is as follows:

"When we get report, then we try that, we inform all our shopkeepers that so and so is the issue ... what should we do now? They tell us we have stock ... if they don't have, then they say we are almost out of stock and hence you should load the stock at once... we send them at once ... after few days, flood comes." (WS2-C2R2)

These early warnings enable the alignment of processes between different partners in the supply chain. This fast sharing of information also helps speedy responses and the prepositioning of inventory in advance of an event, and thus, contributes to achieving resilience. The research data revealed that telecommunications and other media plays also play a critical part in achieving flexibility in these chains, as explained in the following example:

"We mostly connect with our buyers through mobile phone, it is easier, and it saves us lots of time and energy to travel to these areas. We develop the relationship and then be in contact through cell phones." (WS2-C2R2) (CA1-C1R1)

The key insights here are that effective communication and information sharing facilitate the resilience aspects of flexibility and adaptation. These practices help these supply chains continue supplying customers with goods in the response and recovery phases.

\section{Mutual Dependence}

Mutual dependence is one of the core reasons these supply chain firms share information and communicate with each other in times of disruption. As most of the farmers do not have knowledge of and access to wholesale markets, they are highly dependent on middlemen and commission agents who ensure that their products reach the final consumers. In addition, farmers generally have no formal sources of finance or credit, and thus, they again turn to their respective commission agents for loans and financing. As such, whenever a farmer is in trouble due to a natural disaster or other social problems, the commission agent's finances are also at stake. Hence, they work together to share information and take actions to mitigate any losses for both parties. Thus, it can be said that there is a high level of mutual dependence and concession in these relationships. They 
also use barter transactions instead of money and deal in goods to replace cash. They also share missing information to reduce information asymmetry. This dependency aligns the interest of the different firms involved and networks evolve naturally, in a way that they become dependent upon each other. For example, one respondent stated,

" ... however, because of the trusted sustainable buyers and suppliers, also because of dependency on each other being part of same supply chain, their supplier and buyers shared the missing information with them." (LP1-C1R2)

This dependence also increases adaptive resilience in the aftermath of disasters; as another respondent commented,

"... [the] commission agent has invested in them, so the farmers are not in position they can pay back the debt so based on our recommendation, commission agent relax the payback time. Everyone waits for the next year and we trust our God that he will give us the prosperity next year." (MM1-C1R1)

In these relationships, commission agents always hold more power (due to their market position, greater resources, and financial investments). Any deals between farmers and commission agents typically favour the latter. However, the market committee (a loose body made up of respected members of the local trading community) present in these wholesale markets regulate the prices and ensure a degree of fairness for the farmers. Mutual dependence has been observed in the supply chains of C1R1, C1R2, and C2R1, as these chains are dominated by large wholesalers (hubs) with multiple firms (nodes) attached to them, both upstream and downstream.

\subsubsection{Non-Institutional Financial Support}

One of the main vulnerabilities of both regions studied is the lack of formal financing options or financial institutions, such as second-tier lenders that would typically be seen in a more developed market economy. Although there are a number of banks available, their high costs and complex products are significant barriers to engagement. Hence, the emergence of non-institutional financial support is a relatively unique feature of these case study supply chains and plays an important role in both of these regions. This noninstitutional financial support is a key feature of these chains that also helps facilitate alignment, flexibility, adaptability, and velocity in these networks, and hence, is a key building block for supply chain resilience.

Many commission agents, in both R1 and R2, reported that they invest directly in the farmers. By investing in their key suppliers, all parties become mutually dependent. This financial dependence is important when disaster strikes farmers. As one respondent noted,

"... [we] give money to farmers and also arrange fertilizers or other raw material for him to help him grow the crops again, we also seek help from some of the investors and dealers, therefore also jointly invest on farmers and growers. We can sometime buy them tractor and give money for labour hiring as well." (CA1-C1R2)

This investment goes beyond contingency planning but is seen as a normal part of business operations that helps to secure regular supplies and improve quality. When floods or earthquakes strike and crops are destroyed, these same commission agents will again provide loans to these farmers so that they can recover quickly and maintain, as much as possible, continuity of the supply.

These efforts increase the speed of recovery, as other financial institutes are very slow to process transactions. These agents deduct loan instalments as promised, however, there is a great deal of flexibility in loan paybacks. As such, both parties become bound to each other, and the incentives become aligned. Flexibility in payback is important for the recovery of other supply chain firms after the disaster as well (especially the middlemen and farmers). For example, when asked how they deal with loan repayments if their suppliers face a natural calamity, one of the respondents stated, 
"They are totally relaxed, some say they will return next year and some put other conditions, but we negotiate and come to solution and give them maximum time." (Pr1-C1R2)

Although flexibility is present, they negotiate first and set up the terms. The negotiation is based on several factors, including the degree of mutual trust and the magnitude of disruption. One purpose of these negotiations is to set the terms and conditions; another big reason is to align the results of each party so that everyone benefits and businesses survive.

\subsubsection{Utilizing Network Resources}

Another important component of collaboration is utilizing the network resources outside of one's own control or ownership. This component has activities that are related to the sharing of resources and making the most of the available resources in the networks, especially in difficult times, when the primary aim is to survive the disaster.

Sharing logistics functions and activities is prevalent in these supply networks. There were numerous instances recorded where one of the supply chain partners had arranged transportation on behalf of their buyer or supplier in the case of an emergency-

"... it is the duty of supplier to manage all the transportation, but in some emergency cases we send our own vehicle to collect the supplies." (Tr-C2R1)

This quick response by sharing resources helps achieve velocity in the network. Other than vehicles, storage facilities are also available near the wholesale markets (hubs) utilized by different firms. These facilities are mostly privately owned by the key actors in these hubs. These are important staging areas for inventory when the supply does not equal the demand and there is excess supply from the farmers. Later, when there is demand for these goods, these items are brought to the wholesale markets for auction. The flexibility of these temporary storage facilities helps cover shortages during disruptions. Resource sharing is mostly seen in the fruit and vegetable wholesale markets in both regions. It has also been observed that where actors are mutually dependent, resource sharing is far more common.

\subsubsection{Trust}

The results have found that building and maintaining trust is a key element in the process of information sharing, financial support, combined logistic activities, and all other collaboration-related activities. A significant finding of this research is the nature of the conflict resolution mechanisms present in these supply networks, especially in Region 2 (R2). Effective conflict resolution increases trust between all supply chain firms because they know that if something goes wrong, any resulting conflicts will be resolved through this special system. In C1R2 and C2R2, conflict resolution is the responsibility of a local committee called 'Jirga' in the local language. A Jirga is formed when there are serious disagreements, such as payment delays, property disputes, or any other issue that cannot be resolved by the parties directly. This is equally helpful for disasters that cause serious disruptions to supplies or finances. For example, one of the market committee members in C1R2 stated,

"[the] farmer has lost everything and dealer has their investment in that farmer through the commission agent. Because of the delay from farmer, there is conflict among all parties then we announce Jirga, market committee member such as vice president, general secretary, chairman, deputy general secretary is part of that Jirga. All the supply chain partners who are part of that conflict also attend the Jirga, we take undertaking from all parties involved that whatever Jirga will decide will be acceptable by everyone." (MC1-C1R2)

A Jirga is a standing committee whose members are mostly reputable elder members of the society who are acceptable to both parties in the dispute, such as farmer representatives, reputable elderly commission agents, or other notable persons in that market. This alternative conflict resolution system has helped local governments and other lawenforcing bodies resolve hundreds of disputes. Indeed, the formal system of justice is already overburdened and slow, which makes this alternative system even more important 
for these parties. Many of the respondents mentioned that the formal judiciary system in the region is slow and expensive, and therefore, they prefer to resolve their disputes via the Jirga.

The Jirga has a simple process that it follows. Both parties or groups appear in front of the panel and present their cases. They are given adequate time, and witnesses from both sides are questioned. In serious cases, both parties swear an oath (while holding their hand on a religious book). The decision is made based on the majority opinion. As the market committee is also involved in the Jirga, it has government support as well. This conflict resolution process also helps individuals adapt to new situations quickly in the aftermath of a disaster. As one respondent stated,

"Jirga is also called when farmer delays the payment and we compromise with the dealers, we ask both of them and we take undertaking that whatever Jirga will decide will be acceptable by both of you." (WS1-C2R2)

The next major aspect of collaboration is horizontal collaboration, and it is discussed in Section 4.2.

\subsection{Horizontal Collaboration}

Collaboration among suppliers and buyers (vertical) is important to prepare, respond to, and recover from natural disasters. However, in rural communities, collaboration among horizontal actors within the same tier of these supply networks as well as with external agencies is equally important. These actors are in an ideal position to help each other in times of crisis. The researchers found that during disruptions, supply chain firms at the horizontal level do indeed collaborate with their competitors and government departments. This analysis grouped horizontal collaboration into two main dimensions-coopetition and collaboration with government agencies.

\subsubsection{Coopetition}

The results found show that firms at the same level, especially at the farmer and hub levels, not only compete but also cooperate with each other, especially during disruptions. There were many occasions in which firms at each tier of the network cooperated with each other to deal with natural disasters; these were farmers, middlemen, wholesalers, and sometimes retailers. Indeed, the data show that information sharing and regular communication with competitors is very common in these supply chains. For example, one commission agent stated that,

"... we regularly communicate with other commission agents [competitors] and share information such as which crop is going good, about suppliers and if we have information about disaster then we also tell other people in market." (CA1-C1R1)

This information sharing helps align the interests of these competitors. Such disasterrelated information helps these actors to plan or cope with disruptions arising from these disasters. These interactions mostly happen at auction-based wholesale markets (C1R1, C2R1, C1R2), where commission agents are co-located. Mill owners are connected with each other through different associations by which they share information. Similarly, in C2R2, wholesalers in the grain market interact with each other in order to find common solutions. Similarly, farmers in the same village who ostensibly compete with each other also communicate and share information, for example, sharing new farming techniques. All of these are examples of horizontal coopetition. Motives for these behaviours include mutual interest and empathy in the face of frequent disruptions. Coopetitive behaviour also extends to the sharing of resources. The results found show that having a common supplier, or the sharing of logistic resources amongst competitors, is prevalent in these supply networks. Resource sharing among actors at the same tier aligns the processes of the firms involved and also contributes to some of the components of supply chain resilience.

In addition to these episodes of resource sharing, these competitors also seek common solutions to disruptions arising from natural disasters. In many places in R2, the data show 
joint investments in irrigation systems amongst actors who are otherwise competitors. Previously, there was no mechanism to store water. These farmers use natural water and have made special irrigation systems to irrigate their crops. As one farmer explained,

"there is Swat river ... you will see ... we all people have 2 to 3 channels for us ... government did not ... we did on our own and from the same every person irrigates land according to one's personal needs ... " (Fr1-C1R2)

These channels were destroyed in the recent earthquake but were rebuilt using money and resources contributed by most of the local farmers. This alignment of interest makes farmers more resilient against these disasters, as they derived their own solutions more quickly compared to others by emphasising collaboration with the competitors. This example highlights the adaptive capabilities of these supply chain actors to new situations.

Overall, coopetition was observed in all four supply chain networks. It has been argued that coopetition helps improve the velocity, flexibility, and alignment of these networks. Nevertheless, there is a lack of uniformity in these interactions. Most often, these are informal interactions initiated out of mutual self-interest and facilitated due to the close-knit culture of these regions. Yet, wherever these competitors have collaborated, the data show that they have responded and recovered from natural disasters more efficiently and effectively than other actors.

\subsubsection{Government Support}

The largest contributing factor towards resilience in the horizontal collaboration category is the support provided by government agencies, especially from provincial and local governments. It was seen that government support facilitates reliability, velocity, and adaptability in these supply networks. It has been found that R1 has more support for these supply networks than R2. The reason is that the local and provincial governments in $\mathrm{R} 1$ are more financially stable than the R2 government.

Through our analysis, we found that there are three main activities within the government support category. The first is policy stability and accountability. The data indicate that policy stability and accountability provided by local and provincial governments are very important for improving resilience in these supply chains. One of the main factors is to normalize the demand and supply in these chains. As previously mentioned, market committees and government bodies help to regulate the functionalities of these networks. During natural disasters, local governments make sure that no one is hoarding produce in order to create artificial shortages in the market. Compliance is enforced through inspection teams visiting market storage places and warehouses in the area. This ensures reliability in these chains through the continuous supply of products to the wholesale market. The government not only ensures that there is no hoarding, but they also impose limits on the amounts that can be purchased by each firm involved in the market to enable consistency in these chains. These measures also align the interest of the whole market. As one government representative in R1 noted,

"... being member of market committee we make sure that demand and supply are consistent in the market and there is no artificial shortage, we do surveys and have inspection teams who go to each go down to make sure there is no extra storage of products, if there is deliberate shortage created by some party we impose heavy penalties on them." (GR1-C1R1)

These practices help the overall functionality and velocity of these supply chains and ensure they are able to return to normal operations as quickly as possible.

The second factor is the provision of financial support. This support is provided in a variety of ways; however, financial support is focused mainly on the farmers. One of the respondents reported that,

"[The] government announces special packages for farmers after major disaster it can be in form of cash and there are also loan programs from bank, this helps the farmers to spring back quickly." (CA3-C1R2) 
There are many other forms of support that are provided to these networks at different levels by the government, such as a relaxation of bank interest, cash distributions, temporary tax exemptions, loan programs for farmers, and the provision of raw materials. All these measures help these actors to adapt to new situations that arise from disruptions. Nevertheless, while this centralised government support provides relief to these networks, it is the non-institutional financial support that remains the largest form of assistance for these chains.

The third and final factor is the government's role in maintaining and improving physical infrastructure. In particular, this analysis highlighted the need for creating safety walls/stop banks alongside the Swat river as one of the fundamental responsibilities of the government to protect the crops and cities from floods. Often, these safety walls are actually built, but due to corruption, the material used in these walls is not of good quality. Failure is all too frequent and ultimately results in crop losses. One respondent lamented,

"there was so much rain and flood ... safety walls were broken ... there are corrupt people ... banks are made up of soil and not cement ... every year the rains demolish it ... they say it broke from here ... this happen and that happened ... we keep on waiting." (Fr1-C1R2)

There were other instances in which the respondents were positive about these safety walls. Hence, if elements of corruption could be minimized, then even more resilience could be achieved against these floods. The respondents identified a number of other elements that would help to protect their businesses, including draining flood water, reinstating bridges, road construction, and an efficient canal system. Building reliability into the physical infrastructure is important both for the preparation phase and for ensuring the continuity of supplies during the response phase.

\section{Discussion}

This research has provided empirical insights into the key components of collaboration and some of the important activities that contribute to food supply chain resilience in a developing economy. There are several collaborative activities that occur in supply chains. These include information sharing, resource sharing, communication, and incentive alignment [20,53]. Collaboration also happens at both vertical and horizontal levels [77], and was evident in this analysis. At the vertical level, collaboration happens among supply chain partners, such as retailers, wholesalers, processors, and growers, while at a horizontal level, it occurs within groups of competitors as well as within government departments.

For vertical collaboration, effective communication and information sharing is one of the most important components of supply chain collaboration. Relationships between supply chain partners depend on the information that is visible across the supply chain [78], particularly, information about disruptions or any changes within the supply chain. This information can only be acquired by communicating with the other supply chain members. It also allows supply chain members to have advanced warning of events and hence, to make appropriate preparations [79]. Through our analysis, we have found that information sharing and communication is achieved primarily through the effective use of telecommunication, site visits, and above all, mutual dependency through tight social relationships.

Mutual dependence is a necessary attribute that contributes to communication and information sharing among supply chain members. This finding confirms the verdict of Soosay and Hyland [80], who argue that mutual dependency is the rationale for different firms in supply chains assisting each other when dealing with disruptions. Indeed, mutual dependency helps these networks be flexible and adapt to new situations quickly. However, Scholten and Schilder [20] argue that mutual dependency increases dedicated investments, which in return, decreases flexibility. Yet, this analysis found that resilience actually increased, and this is due to there being no other major (institutional) financial support available to these supply networks. 
Indeed, one of the most significant findings for the concept of collaboration in resilience is the non-institutional financial support available in these regions. This finding is rooted in the resource dependence theory that states that powerful firms in a supply network help less powerful partners in a mutually beneficial arrangement [54]. These powerful actors (in this research, those located in the main wholesale markets or hubs) provide financial support to both upstream and downstream members of the network. Nevertheless, this may decrease flexibility due to path dependency, as shared resources tend to get 'locked in' over time. However, in terms of credit return and lead time, these findings show that noninstitutional financial support increases flexibility. In addition, the results of this research also show that alignment, adaptability, and velocity also increase due to the availability of non-institutional financial support, and are, thus, key factors in the resilience of these supply chains $[81,82]$.

Another important insight relates to the role of a chain coordinator or lead actor in facilitating collaboration among the partners to achieve supply chain resilience [13]. This phenomenon is mostly discussed in humanitarian chains in which, often, a lead reliefproviding organization emerges or is appointed as a centralised coordinator. In terms of commercial food chains, this is also significant, as these lead firms tend to be large-scale retailers or distributors [83]. However, in this study, many independent firms in hub markets, as a closely aligned inter-dependent group, were the main chain coordinators. They provide financial support to the less powerful members of these chains in both regions. As Akhtar and Marr [13] point out, chain coordinators act as a catalyst, thus ensuring effective coordination among different supply chain members; this coordination contributes to the agility, alignment, and adaptability of these chain actors. The results of this research confirm this finding and show that it is the close social networks, cultural norms, and mutual dependency created through the financial support of the chain coordinators and by their commitment to other actors that make these supply chains aligned, agile, and adaptive.

Stevenson and Spring [84] argue that inter-firm information and resource sharing leads to supply chain flexibility. Indeed, the results of this analysis confirm this finding, as labour and transport sharing is very common in all four supply chains. Subsequently, the analysis has also highlighted that this practice not only facilitates flexibility but also increases the velocity of operations due to resource sharing, thus leading to more resilient supply chains. Thus, in this study, it is argued that despite some major impediments, these chains collaborate well across the vertical tiers of the supply chain.

At the horizontal collaborative level, competitors were also found to share resources and information, supporting each other financially and seeking common solutions. This phenomenon of simultaneously competing and collaborating with competitors is often described as 'coopetition' [48]. In this study, drivers of coopetition were mostly contextual. The results of this analysis confirm that network dynamics push firms to cooperate with their competitors in order to survive disasters [85]. It can also be called 'emergent coopetition', as it arises mostly in difficult times [86]. However, we also observed some structural coopetition that takes the form of more planned coopetition driven by the buyers in these supply chains [87]. For example, structural coopetition was observed when buyers urged two otherwise disconnected suppliers to collaborate with each other through training programs.

Scholten and Schilder [20] stated that collaborative activities between competitors lead to flexibility and velocity in supply networks. This study adds to this finding and the results show that besides increasing flexibility and velocity, coopetition helps achieve adaptability through financial support and supply chain alignment via the sharing of information. Therefore, these findings confirm that supply chain resilience can be enhanced through coopetition.

Furthermore, at the horizontal level, we have found that government support is an important component of supply chain collaboration. This is in agreement with the work of Cai and Jun [88], Van Wassenhove [89], and Balcik and Beamon [90], who all found that government support is an important element of collaboration within relief supply chains. 
This is especially true at the local government level, as they have a more direct influence on local business activities by implementing economic and disaster relief policies. Hence, government support assists velocity in relief efforts as well as helping firms to adapt to new situations by supporting them financially and through improved infrastructure in both the preparation and recovery phases. This improved infrastructure is crucial for coping with future disasters as well. This research also confirms that government support in food supply networks is a major contributing factor for adaptability, velocity, and reliability, thus increasing supply chain resilience. However, there are greater vulnerabilities associated with this activity, including corruption, poor policies, poor planning, and the undue influence of strong political and business parties. If these issues could be improved, the resilience of these food supply chains would be greatly enhanced.

Finally, building and maintaining trust is essential because, without this, both vertical and horizontal collaborations are impossible. The results of this research previously identified the mutual dependency of actors as a driving force towards collaboration. Additionally, this mutual dependency is enhanced by trust in these relationships. Many authors have discussed trust as the building block of supply chain agility, as it helps visibility, reliability, velocity, and flexibility [91,92]. We found that building and maintaining trust mostly originates from social norms within these regions and that a high level of trust helps to achieve agility, adaptability, and alignment. The most important finding in this component is the conflict resolution mechanism discussed in the findings section. This conflict resolution process (Jirga and the market committee) provides a high degree of confidence within these chains and, ultimately, builds trust. Conflict management during natural disasters also enables flexibility and velocity, two important factors for disaster responses.

Overall, the contribution of supply chain collaboration to supply chain resilience can be seen as positive. Both vertical and horizontal collaborations increase supply chain resilience by enhancing agility, adaptability, and alignment.

\section{Conclusions}

Previous research has focused primarily on collaboration as the central component of supply chain resilience. However, this research was focused more on finding the extant underlying activities within collaborative efforts that are associated with supply chain resilience in a developing country context. At the vertical level, we found that effective communication and information sharing are some of the most important components of supply chain collaboration. Relationships between supply chain actors depend on information sharing that is visible across the supply chain [78]. Particular information (about disruptions or any changes within the supply chain) can be acquired by communicating with other supply chain actors [79]. These activities enable visibility and flexibility in supply chains to respond to difficult situations [93].

Mutual dependence can be considered one of the main contributions to communication and information sharing among supply chain members. Mutual dependency equates to interdependence, and therefore, when dealing with natural disasters, actors coalesce to resolve the situation; this is especially true in these rural communities, as actors have close family ties with each other. Mutual dependence has both negative and positive effects on normal business operations. While it reduces the flexibility of switching to different suppliers and potential buyers, in difficult times, it helps the network to respond and recover more quickly and effectively.

One of the main vulnerabilities in these rural regions studied is the lack of formal financing options or financial institutions, such as second-tier lenders that would typically be seen in a free market economy. Although there are multiple banks available, their high costs and complex products are significant barriers to engagement. Thus, local food supply chain firms (especially small-scale businesses) are reluctant to use their services. This is compensated by the presence of non-institutional financial support (mostly provided by commission agents) available in these regions, especially when the hub is providing the support. This support is a very important contributor to adaptability and also contributes 
positively to aligning the interests of supply chain members. We conclude that chain coordinators, through their commitment and support for other members, make the supply chain more aligned, agile, and adaptive.

In addition to vertical collaboration, competitors at the same horizontal level also share resources and information, supporting each other financially and seeking common solutions. This is known as coopetition [48]. Network dynamics encourage firms to cooperate with their competitors to survive disasters [85]. Scholten and Schilder [20] stated that collaborative activities between competitors lead to flexibility and velocity in supply networks. One contribution of this research is showing that besides flexibility and velocity, coopetition helps achieve adaptability (through financial support) and supply chain alignment (through sharing information).

The results of this research also confirm that government support in food supply networks is a significant contributing factor for promoting adaptability, velocity, and reliability, thus increasing supply chain resilience. There are, of course, greater vulnerabilities associated with this activity, such as corruption, poor policies, poor planning, and the influence of strong parties. However, if these issues could be resolved, there would be a marked increase in the overall resilience of these chains.

Finally, building and maintaining trust is essential, because, without these, both vertical and horizontal collaborations are impossible. Through our research, we found that trust mostly originates from social norms within these regions, and that a high level of trust helps to achieve agility, adaptability, and alignment. The presence of the special conflict resolution process (Jirga and the market committee) provides a high degree of confidence within these chains and ultimately builds trust. Nevertheless, conflict management is an important activity, as many conflicts arise during difficult times in these food chains. This Jirga system is rather unique in the context of global supply chains, yet understanding the conflict resolution processes and trust-building aspects of this mechanism contributes to the debate on the drivers of supply chain resilience.

Author Contributions: The authors confirm contribution to the paper as follows: study conception and design: M.U. and M.W.; data collection: M.U.; analysis and interpretation of results: M.U. and M.W.; draft manuscript preparation: M.U. and M.W. All authors reviewed the results and approved the final version of the manuscript.

Funding: APC will be funded by Lincoln University.

Conflicts of Interest: The authors declare no conflict of interest.

\section{References}

1. Bozarth, C.C.; Handfield, R.B. Introduction to Operations and Supply Chain Management; Pearson: London, UK, 2016.

2. Ponomarov, S. Antecedents and Consequences of Supply Chain Resilience: A Dynamic Capabilities Perspective; University of Tennessee: Knoxville, TN, USA, 2012.

3. Handfield, R.B.; Blackhurst, J.; Elkins, D.; Craighead, C.W. A framework for reducing the impact of disruptions to the supply chain: Observations from multiple executives. In Supply Chain Risk Management: Minimizing Disruption in Global Sourcing; Taylor and Francis: Boca Raton, FL, USA, 2007; pp. 29-49.

4. Haghani, A.; Afshar, A. Supply Chain Management in Disaster Response. 2009. Available online: https://rosap.ntl.bts.gov/ view/dot/34430 (accessed on 23 September 2020).

5. Van Opstal, D. The Resilient Economy: Integrating Competitiveness and Security; Council on Competitiveness: Washington, DC, USA, 2007.

6. Sheffi, Y.; Rice, J.B., Jr. A supply chain view of the resilient enterprise. MIT Sloan Manag. Rev. 2005, 47, 41.

7. Christopher, M.; Peck, H. Building the resilient supply chain. Int. J. Logist. Manag. 2004, 15, 1-14. [CrossRef]

8. Folke, C.; Carpenter, S.R.; Walker, B.; Scheffer, M.; Chapin, T.; Rockström, J. Resilience thinking: Integrating resilience, adaptability and transformability. Ecol. Soc. 2010, 15, 20. [CrossRef]

9. Cao, M.; Zhang, Q. Supply chain collaboration: Impact on collaborative advantage and firm performance. J. Oper. Manag. 2011, 29, 163-180. [CrossRef]

10. Maon, F.; Lindgreen, A.; Vanhamme, J. Developing supply chains in disaster relief operations through cross-sector socially oriented collaborations: A theoretical model. Supply Chain Manag. Int. J. 2009, 14, 149-164. [CrossRef]

11. Jüttner, U.; Peck, H.; Christopher, M. Supply chain risk management: Outlining an agenda for future research. Int. J. Logist. Res. Appl. 2003, 6, 197-210. [CrossRef] 
12. Christopher, M.; Rutherford, C. Creating supply chain resilience through agile six sigma. Crit. Eye 2004, $24,28$.

13. Akhtar, P.; Marr, N.; Garnevska, E. Coordination in humanitarian relief chains: Chain coordinators. J. Humanit. Logist. Supply Chain Manag. 2012, 2, 85-103. [CrossRef]

14. Ponomarov, S.; Holcomb, M.C. Understanding the concept of supply chain resilience. Int. J. Logist. Manag. 2009, $20,124-143$.

15. Pérouse de Montclos, M.-A. Humanitarian action in developing countries: Who evaluates who? Eval. Program Plan. 2012, 35, 154-160. [CrossRef]

16. Tariq, M.A.U.R.; van de Giesen, N. Floods and flood management in Pakistan. Phys. Chem. Earth Parts A B C 2012, 47, 11-20. [CrossRef]

17. Ozcan, P.; Eisenhardt, K.M. Origin of alliance portfolios: Entrepreneurs, network strategies, and firm performance. Acad. Manag. J. 2009, 52, 246-279. [CrossRef]

18. Dyer, J.H.; Singh, H. The relational view: Cooperative strategy and sources of interorganizational competitive advantage. Acad. Manag. Rev. 1998, 23, 660-679. [CrossRef]

19. Lee, G.K. The significance of network resources in the race to enter emerging product markets: The convergence of telephony communications and computer networking, 1989-2001. Strateg. Manag. J. 2007, 28, 17-37. [CrossRef]

20. Scholten, K.; Schilder, S. The role of collaboration in supply chain resilience. Supply Chain Manag. Int. J. 2015, 20, 471-484. [CrossRef]

21. Wilhelm, M.M. Managing coopetition through horizontal supply chain relations: Linking dyadic and network levels of analysis. J. Oper. Manag. 2011, 29, 663-676. [CrossRef]

22. Tan, K.C. A framework of supply chain management literature. Eur. J. Purch. Supply Manag. 2001, 7, 39-48. [CrossRef]

23. Wagner, S.M.; Bode, C. Dominant risks and risk management practices in supply chains. In Supply Chain Risk; Springer: Boston, MA, USA, 2009; pp. 271-290.

24. Starr, R.; Newfrock, J.; Delurey, M. Enterprise resilience: Managing risk in the networked economy. Strategy Bus. 2003, 30, 70-79.

25. Pettit, T.J.; Fiksel, J.; Croxton, K.L. Ensuring supply chain resilience: Development of a conceptual framework. J. Bus. Logist. 2010, 31, 1-21. [CrossRef]

26. Fiksel, J. Sustainability and resilience: Toward a systems approach. Sustain. Sci. Pract. Policy 2006, 2, 14-21. [CrossRef]

27. Masten, A.S.; Reed, M.G.J. Resilience in Development. In The Oxford Handbook of Positive Psychology; Oxford University Press: Oxford, UK, 2009; p. 117.

28. Folke, C.; Carpenter, S.; Walker, B.; Scheffer, M.; Elmqvist, T.; Gunderson, L.; Holling, C.S. Regime shifts, resilience, and biodiversity in ecosystem management. Annu. Rev. Ecol. Evol. Syst. 2004, 35, 557-581. [CrossRef]

29. Berkes, F. Understanding uncertainty and reducing vulnerability: Lessons from resilience thinking. Nat. Hazards 2007, 41, 283-295. [CrossRef]

30. Chowdhury, M.M.H.; Quaddus, M.; Agarwal, R. Supply chain resilience for performance: Role of relational practices and network complexities. Supply Chain Manag. Int. J. 2019, 24, 659-676. [CrossRef]

31. Zakour, M.J.; Gillespie, D.F. Resilience Complements Vulnerability. In Community Disaster Vulnerability; Springer: Berlin/Heidelberg, Germany, 2013; pp. 55-71.

32. Remko, V.H. Research opportunities for a more resilient post-COVID-19 supply chain-closing the gap between research findings and industry practice. Int. J. Oper. Prod. Manag. 2020, 40, 341-355. [CrossRef]

33. Tukamuhabwa, B.R.; Stevenson, M.; Busby, J.; Zorzini, M. Supply chain resilience: Definition, review and theoretical foundations for further study. Int. J. Prod. Res. 2015, 53, 5592-5623. [CrossRef]

34. Park, K. Flexible and Redundant Supply Chain Practices to Build Strategic Supply Chain Resilience: Contingent and Resource-Based Perspectives; University of Toledo: Toledo, OH, USA, 2011.

35. Ali, A.; Mahfouz, A.; Arisha, A. Analysing supply chain resilience: Integrating the constructs in a concept mapping framework via a systematic literature review. Supply Chain Manag. Int. J. 2017, 22, 16-39. [CrossRef]

36. Jackson, S.; Ferris, T. Proactive and Reactive Resilience: A Comparison of Perspectives. Available online: https:/ /www.academia. edu/34079700/Proactive_and_Reactive_Resilience_A_Comparison_of_Perspectives (accessed on 23 September 2020).

37. Goranson, H.T. The Agile Virtual Enterprise: Cases, Metrics, Tools; Greenwood Publishing Group: Santa Barbara, CA, USA, 1999.

38. Stevenson, M.; Spring, M. Flexibility from a supply chain perspective: Definition and review. Int. J. Oper. Prod. Manag. 2007, 27, 685-713. [CrossRef]

39. Rice, J.B.; Caniato, F. Building a Secure and Resilient Supply Network. Supply Chain Manag. Rev. 2003, 7, 22-30.

40. Lee, H.L. The triple-A supply chain. Harv. Bus. Rev. 2004, 82, 102-113.

41. Chiang, C.-Y.; Kocabasoglu-Hillmer, C.; Suresh, N. An empirical investigation of the impact of strategic sourcing and flexibility on firm's supply chain agility. Int. J. Oper. Prod. Manag. 2012, 32, 49-78. [CrossRef]

42. Dubey, R.; Gunasekaran, A. The sustainable humanitarian supply chain design: Agility, adaptability and alignment. Int. J. Logist. Res. Appl. 2016, 19, 62-82. [CrossRef]

43. Aitken, J.; Christopher, M.; Towill, D. Understanding, implementing and exploiting agility and leanness. Int. J. Logist. 2002, 5, 59-74. [CrossRef]

44. Baramichai, M.; Zimmers, E.W., Jr.; Marangos, C. Agile supply chain transformation matrix: A QFD-based tool for improving enterprise agility. Int. J. Value Chain Manag. 2007, 1, 281-303. [CrossRef]

45. Brooks, N. Vulnerability, risk and adaptation: A conceptual framework. Tyndall Cent. Clim. Chang. Res. Work. Pap. 2003, 38, 1-16. 
46. Keogh, D.U.; Apan, A.; Mushtaq, S.; King, D.; Thomas, M. Resilience, vulnerability and adaptive capacity of an inland rural town prone to flooding: A climate change adaptation case study of Charleville, Queensland, Australia. Nat. Hazards 2011, 59, 699-723. [CrossRef]

47. Vogus, T.J.; Sutcliffe, K.M. Organizational resilience: Towards a theory and research agenda. In Proceedings of the IEEE International Conference on Systems, Man and Cybernetics, Montreal, QC, Canada, 7-10 October 2007.

48. Bengtsson, M.; Eriksson, J.; Wincent, J. Coopetition: New ideas for a new paradigm. In Coopetition: Winning Strategies for the 21st Century; Edward Elgar Publishing: Northampton, MA, USA, 2010; pp. $19-39$.

49. Simatupang, T.M.; Sridharan, R. The collaborative supply chain. Int. J. Logist. Manag. 2002, 13, 15-30. [CrossRef]

50. Barratt, M. Understanding the meaning of collaboration in the supply chain. Supply Chain Manag. Int. J. 2004, 9, 30-42. [CrossRef]

51. Piboonrungroj, P.; Disney, S.M. Supply chain collaboration in tourism: A transaction cost economics analysis. Int. J. Supply Chain Manag. 2015, 4, 25-31.

52. Knoppen, D.; Christiaanse, E. Supply chain partnering: A temporal multidisciplinary approach. Supply Chain Manag. Int. J. 2007, 12, 164-171. [CrossRef]

53. Cao, M.; Zhang, Q. Supply Chain Collaboration: Roles of Interorganizational Systems, Trust, and Collaborative Culture; Springer Science \& Business Media: Berlin/Heidelberg, Germany, 2012.

54. Min, S.; Roath, A.S.; Daugherty, P.J.; Genchev, S.E.; Chen, H.; Arndt, A.D.; Richey, R.G. Supply chain collaboration: What's happening? Int. J. Logist. Manag. 2005, 16, 237-256. [CrossRef]

55. Kim, K.K.; Umanath, N.S.; Kim, B.H. An assessment of electronic information transfer in B2B supply-channel relationships. J. Manag. Inf. Syst. 2005, 22, 294-320. [CrossRef]

56. Prahinski, C.; Benton, W. Supplier evaluations: Communication strategies to improve supplier performance. J. Oper. Manag. 2004, 22, 39-62. [CrossRef]

57. Hardy, C.; Phillips, N.; Lawrence, T.B. Resources, knowledge and influence: The organizational effects of interorganizational collaboration. J. Manag. Stud. 2003, 40, 321-347. [CrossRef]

58. Acharyulu, A.; Mathew, A. Food supply chains and their influence on resurgence in institutions of Commons. In Proceedings of the 11th Global conference of IASCP, Bali, Indonesia, 19-23 June 2006.

59. Farhat, R. Management of logistics and ICT in food supply chain network: A conceptual framework. Int. J. Logist. Econ. Glob. 2012, 4, 163-178. [CrossRef]

60. Campbell, A.M.; MacRae, R. Local Food Plus: The connective tissue in local/sustainable supply chain development. Local Environ. 2013, 18, 557-566. [CrossRef]

61. Dani, S.; Deep, A. Fragile food supply chains: Reacting to risks. Int. J. Logist. Res. Appl. 2010, 13, 395-410. [CrossRef]

62. Leat, P.; Revoredo-Giha, C. Risk and resilience in agri-food supply chains: The case of the ASDA PorkLink supply chain in Scotland. Supply Chain Manag. Int. J. 2013, 18, 219-231. [CrossRef]

63. Singh-Peterson, L.; Lawrence, G. Insights into community vulnerability and resilience following natural disasters: Perspectives with food retailers in Northern NSW, Australia. Local Environ. 2015, 20, 782-795. [CrossRef]

64. Kalidas, K.; Jiji, S.; Sureka, M. Supply Chain Management in Vegetables. Indian J. Res. 2014, 3, 315-316. [CrossRef]

65. Douglas, I. Climate change, flooding and food security in south Asia. Food Secur. 2009, 1, 127-136. [CrossRef]

66. Aggarwal, P.; Joshi, P.K.; Ingram, J.S.; Gupta, R.K. Adapting food systems of the Indo-Gangetic plains to global environmental change: Key information needs to improve policy formulation. Environ. Sci. Policy 2004, 7, 487-498. [CrossRef]

67. López-Marrero, T.; Tschakert, P. From theory to practice: Building more resilient communities in flood-prone areas. Environ. Urban. 2011, 23, 229-249. [CrossRef]

68. Berkes, F.; Ross, H. Community resilience: Toward an integrated approach. Soc. Nat. Resour. 2013, 26, 5-20. [CrossRef]

69. Guarnizo, C.C. Living with Hazards Communities Adjustment Mechanisms in Developing Countries; World Bank: Washington, DC, USA, 1992.

70. Tomasini, R.M.; Wassenhove, L.N. Humanitarian Logistics; Palgrave Macmillan: London, UK, 2009.

71. Yin, R. Case Study Research: Design and Methods; Sage Publications: Thousand Oaks, CA, USA, 2014.

72. Miles, M.B.; Huberman, A.M.; Saldana, J. Qualitative Data Analysis: A Methods Sourcebook; SAGE Publications, Incorporated: Newbury Park, CA, USA, 2013.

73. Khan, A. Agricultural development in Khyber Pakhtun Khwa, prospects, challenges and Policy options. Pak. J. Pak. Stud. 2012, 4, 49-68.

74. Liu, F.; Maitlis, S.; Mills, A.J.; Durepos, G.; Wiebe, E. Encyclopedia of Case Study Research; Sage Publications: Thousand Oaks, CA, USA, 2010; Volume 2.

75. Kvale, S.; Brinkmann, S. Interviews: Learning the Craft of Qualitative Research Interviewing; Sage: Thousand Oaks, CA, USA, 2009.

76. Silver, C.; Lewins, A. Using Software in Qualitative Research: A Step-By-Step Guide; Sage: Thousand Oaks, CA, USA, 2014.

77. Scholten, K.; Scott, P.S.; Fynes, B. Mitigation processes-antecedents for building supply chain resilience. Supply Chain Manag. Int. J. 2014, 19, 211-228. [CrossRef]

78. Holweg, M.; Pil, F.K. Theoretical perspectives on the coordination of supply chains. J. Oper. Manag. 2008, 26, 389-406. [CrossRef]

79. Ritchie, B.; Brindley, C. Supply chain risk management and performance: A guiding framework for future development. Int. J. Oper. Prod. Manag. 2007, 27, 303-322. [CrossRef] 
80. Soosay, C.A.; Hyland, P.W.; Ferrer, M. Supply chain collaboration: Capabilities for continuous innovation. Supply Chain Manag. Int. J. 2008, 13, 160-169. [CrossRef]

81. Mentzer, J.T.; DeWitt, W.; Keebler, J.S.; Min, S.; Nix, N.W.; Smith, C.D.; Zacharia, Z.G. Defining supply chain management. J. Bus. Logist. 2001, 22, 1-25. [CrossRef]

82. Gligor, D.M.; Holcomb, M.C. Understanding the role of logistics capabilities in achieving supply chain agility: A systematic literature review. Supply Chain Manag. Int. J. 2012, 17, 438-453. [CrossRef]

83. Belaya, V.; Gagalyuk, T.; Hanf, J. Measuring asymmetrical power distribution in supply chain networks: What is the appropriate method? J. Relatsh. Mark. 2009, 8, 165-193. [CrossRef]

84. Stevenson, M.; Spring, M. Supply chain flexibility: An inter-firm empirical study. Int. J. Oper. Prod. Manag. 2009, 29, 946-971. [CrossRef]

85. Gnyawali, D.R.; Park, B.J.R. Co-opetition and technological innovation in small and medium-sized enterprises: A multilevel conceptual model. J. Small Bus. Manag. 2009, 47, 308-330. [CrossRef]

86. Kylänen, M.; Rusko, R. Unintentional coopetition in the service industries: The case of Pyhä-Luosto tourism destination in the Finnish Lapland. Eur. Manag. J. 2011, 29, 193-205. [CrossRef]

87. Pathak, S.D.; Wu, Z.; Johnston, D. Toward a structural view of co-opetition in supply networks. J. Oper. Manag. 2014, 32, 254-267. [CrossRef]

88. Cai, S.; Jun, M.; Yang, Z. Implementing supply chain information integration in China: The role of institutional forces and trust. J. Oper. Manag. 2010, 28, 257-268. [CrossRef]

89. Van Wassenhove, L.N. Humanitarian aid logistics: Supply chain management in high geart. J. Oper. Res. Soc. 2006, 57, 475-489. [CrossRef]

90. Balcik, B.; Beamon, B.M.; Krejci, C.C.; Muramatsu, K.M.; Ramirez, M. Coordination in humanitarian relief chains: Practices, challenges and opportunities. Int. J. Prod. Econ. 2010, 126, 22-34. [CrossRef]

91. Narasimhan, R.; Mahapatra, S.; Arlbjørn, J.S. Impact of relational norms, supplier development and trust on supplier performance. Oper. Manag. Res. 2008, 1, 24-30. [CrossRef]

92. Yang, J. Supply chain agility: Securing performance for Chinese manufacturers. Int. J. Prod. Econ. 2014, 150, 104-113. [CrossRef]

93. Barnett, C.K.; Pratt, M.G. From threat-rigidity to flexibility-Toward a learning model of autogenic crisis in organizations. J. Organ. Chang. Manag. 2000, 13, 74-88. [CrossRef] 